\title{
COVID-19: A Critical Review on Viral Biochemistry, Environmental Transmission, Therapeutics and Safety Measures
}

\author{
Roshni Kumari, Kumari P. Nanda, Hena Firdaus and Soumen Dey
}

\section{ABSTRACT}

The outbreak of coronavirus disease caused by severe acute respiratory syndrome coronavirus 2 (SARS-CoV-2) is declared pandemic by World Health Organization (WHO) keeping in view its infection rate and toxicity level. The entire world is struggling hard to survive the prevailing health emergency. The authors realise the urgent need of contributing an overview of the present scenario to the researchers who are breathlessly trying to combat this pandemic situation. This review aimed at binding all the scattered data and research available till now on COVID-19 disease starting from its origin to transmission and spread through environmental factors till treatment and the safety measures that should be implemented. This article would possibly help the readers by providing an outlook of current scenario on various perspectives of COVID-19 disease at a single glance. The types, origin and toxicity caused are discussed in brief. The role of contaminated aerosols (viral-laden smoke from tobacco, cigarettes), wastewater, fomites, human and faecal matter are important in spreading the novel coronavirus in the environment. There is no specific treatment till date but clinical trials and diagnosis on several known drugs are on-going. The precaution and safety measures could hopefully reduce number of infections and mortality. The number of infected cases confirmed till 2 August 2020 was 17660523 with 680894 deaths in the world. We tried in this review article to summarize the scattered data available on biochemistry of SARS-CoV-2, environmental spread of virus and the safety measures to combat COVID-19 pandemic.

Keywords: COVID-19, Therapeutics, Transmission, Safety measures and Viral biochemistry.
Published Online: December 19,2020

ISSN: $2684-5199$

DOI:10.24018/ejbio.2020.1.6.125

\section{R. Kumari}

PhD, Department of Chemistry, Central University of Jharkhand, Ranchi,

Jharkhand, India

(e-mail: roshniphd01@ gmail.com)

K. P. Nanda

M.Sc., Department of Life Sciences, Central University of Jharkhand, Ranchi, Jharkhand, India.

(e-mail: kpnanda66@gmail.com)

H. Firdaus*

PhD, Department of Life Sciences, Central University of Jharkhand, Ranchi,

Jharkhand, India.

(e-mail: hena.firdaus@gmail.com)

Soumen Dey*

PhD, Department of Chemistry, Central University of Jharkhand, Ranchi,

Jharkhand, India.

(e-mail: soumen.dey@cuj.ac.in)

"Contributed equally

*Corresponding author

\section{INTRODUCTION}

Coronavirus disease 2019 or COVID-19 was declared a pandemic by WHO on March 11, 2020, because it had spread to almost all the continents and countries across the world. This pandemic started in Wuhan city of Hubei province, China in November 2019 as an outbreak of an unknown pneumonia type virus, whose symptoms were much common with Severe Acute Respiratory Syndrome (SARS) in 2003, Middle East Respiratory Syndrome (MERS) 2013 and other influenza viruses [1].Molecular analysis suggested COVID-19 as a newly evolved branch of coronavirus with high similarity in behavioral pattern and gene sequencing with SARS-Coronavirus (SARS-CoV) and hence was named SARS-CoV-2 by the International Committee on Taxonomy of Viruses [2], [3].This family of $\mathrm{CoV}$ was known to co-infect both humans as well as vertebrates.

\section{ORIGIN AND CLASSIFICATION}

CoVs are classified as member of subfamily Coronavirinae, family Coronaviridae and order Nidovirales. There are four major genera of this subfamily: Alpha-CoVs, Beta-CoVs, Gamma-CoVs, and Delta-CoVs [4], [5]. Alpha and Beta-CoVsare known to infect only mammals originating from primary host bats and rodents while delta and gamma are known to have avian origin, mostly infects birds but some can also infect mammals [6], [4], [5], [1]. Till now seven types of CoVs have been identified: AlphaCoVs include human coronavirus - 229E (HCoV-229E), HCoV-NL63; A-lineage of Beta-CoVscomprise HCoVOC43 and HCoV-HKU1; B-lineage of Beta-CoVs include SARS-CoV-1, SARS-CoV-2 while MERS belongs to Clineage of Beta CoVs [5], [1].

COVID-19 is considered as much more infectious than MERS and SARS [5]. The number of confirmed cases has increased to 17660523 with 680894 deaths worldwide by 2 August 2020 (https://covid19.who.int/) and it is still ongoing due to lack of any definite treatment. Highest death 
per million populations has been reported in United Kingdom (UK) at 627 followed by Spain (606), Italy (573), USA (363), Brazil (241), while country like India has reported very low figure of 10 . This outbreak is becoming alarming as it has potential to spread among the vulnerable targets [7] including immune-compromised persons. Disease spread is also linked with age, as the mortality rate and severity reported is very high in elderly people and children [8].

Specific route for transmission of COVID-19 from its natural reservoir bats to humans is still unknown. Though recent studies suggested pangolin as the intermediate mammalian host because virus isolates from it shared identical spike proteins to SARS-CoV-2 [5], [9], [10]. Besides, recombination, natural selection and mutations are supposedly responsible for the variation in functional part of receptor binding domain (RBD) of spike protein present in SARS-CoV-2 and SARS-CoVs of pangolin, leading to jump of CoVs from bat to pangolins and then to humans [10][13]. While in SARS, 2002 and MERS, 2012 intermediate hosts were reportedly civet cats and infected dromedary camels, respectively [14].

\section{A. Structure, Biochemistry and Genome of SARS-CoV-2}

Structurally, these are virion having a core shell with crown like (Corona in latin means crown) projections protruding outside its near spherical outer shape [1].The diameter of enveloped viral particle COVID-19 virus is between 60-160 nm however it mostly exists in pleomorphic forms [3].These are known to possess the most complex and largest positive sense ssRNA genome of size 27 to $32 \mathrm{~kb}$, which encodes for 9860 amino acids and shared 99.9\% sequence identity in early 9 patients suggesting a recent jump from animal host to humans [15], [5], [16]. These ssRNA possess 5 '-cap structure and 3 '- poly A tail which interacts with nucleoproteins. All CoVs share similarities in genome organization and expression. COVID19 shares $50 \%, 79 \%$ and $96 \%$ genetic similarity to MERS$\mathrm{COV}$, SARS-CoV and other bat SARS related virus, respectively [17], [18], [19]. SARS-CoV-1 and SARS-CoV2 are also known to share angiotensin converting enzyme II (ACE2) as their receptor [12], [16].

The genome of $\mathrm{CoV}$ encodes 4 major structural proteins: the spike protein $(\mathrm{S})$, nucleocapsid protein $(\mathrm{N})$, membrane protein $(\mathrm{M})$, and the envelope protein $(\mathrm{E})$ which are required for production of complete viral particle structurally [20], [21]. The structural diagram of SARS-CoV-2 is shown in Figure 1. $\mathrm{S}$ helps in viral particle entry to the cell by mediating attachment of virus to the receptors on the host cell membrane [21]-[23] and allowing cell fusion [24].S proteins are cleaved into $\mathrm{S} 1$ and $\mathrm{S} 2$ subunits by host proteases like furin, trypsin and endosomal cathepsins, etc. [25] while both subunits play important role in viral entry to the host, $\mathrm{S} 1$ is responsible for receptor binding and S2 for mediating membrane fusion [22].Dimer of S1-S2 forms trimeric complex and folds to acquire a metastable prefusion structure. Although complete organization of spike protein has not yet been identified, limiting our understanding of its mechanism of action. $\mathrm{N}$ protein primarily binds to $\mathrm{CoV}$ RNA building ribonucleoprotein complex [26], [27] though reports also suggest additional role of this structural protein in viral replication and transcription [24].M is considered as the central organizer during coronavirus assembly, as it interacts with all the major structural proteins. Also, it is the most abundant structural protein defining shape to the CoV [20]. The smallest structural protein $\mathrm{E}$ helps in virus assembly, budding and maturation [28], [21].Population genetics analysis of more than 100 SARS-CoV-2 genomes revealed the evolution of CoVs into two major types: $\mathrm{L}$ and $\mathrm{S}$, having two different single nucleotide polymorphisms (SNP). Ltype was more prevalent accounting $70 \%$ of the cases and was more aggressive than S-type (30\%). Early cases reported in Wuhan outbreak in 2019 were reportedly of Ltype but later on it showed a decline in trend after first few months of the year 2020. Although the S-type was believed to be the ancestral version later on its cases increased due to relatively weaker selective pressure [5], [16]. Such rapid transformations in viral genome have led to various epidemics in last two decades, strongly urging us to understand its dynamics to find the solution of health emergencies like COVID-19 in future too.

There are fourteen open reading frames (ORFs) identified in SARS-CoV genome. One third part of genome at the $3^{\prime}$ end possess $12 \mathrm{ORF}$, encodes for structural (S, N. M and E) and accessory proteins [29]-[32]. While 5 '-end comprises of two large overlapping ORF; $1 \mathrm{a}$ and $1 \mathrm{~b}$,encoding for two replicase polyprotein which are cleaved into 16 mature replicase proteins, termed as non-structural proteins (nsp116). These nsp form replication transcription complex (RTC) which are present on endoplasmic reticulum (ER) derived membrane [33]. CoVs are also predicted to code few RNA processing enzymes which are not present in other small RNA viruses [34], [35].

In eukaryotes, mRNA undergoes modification in the nucleus allowing it to possess methylated capped structure at $5^{\prime}$ end responsible for its stability and translation during its cytoplasmic life. But $\mathrm{CoVs}$ which are cytoplasmic replicating eukaryotic viruses have evolved strategies which enables them to cap themselves at $5^{\prime}$ end and also escape from innate immune recognition of the host owing to the presence of unique 2'omethyltransferase (2'-O-MTase) and a complex consisting of 2-subunitsofnsp: nsp16 (catalytic subunit) and nsp10 (stimulatory subunit). Actually, this interface of nsp16-nsp10interaction is unique for CoVs and thus offers a striking target for antiviral drug discovery for CoVs including SARS-CoVs [31]. Several factors are responsible for transmission of viruses such as survival chances of viruses in environment between the hosts [36]. $\mathrm{HCoVs}$ show environmental resistance such as its ability to withstand temperature up to $60-65^{\circ} \mathrm{C}$ [37] and remain alive on different surfaces (wood, steel, etc.) for several hours (3 to 72 hours) [38] greatly enhancing their probability to transfer between hosts through contaminated surfaces such as hands, handles of doors, etc. [39]. Coronavirus enters human body via upper respiratory tract and spread by nasal or mouth droplets. Lack of definitive treatment or vaccine to cure COVID-19 till now, ensures disposal of all the possible disease causing agents through proper adaptation of 
disinfectants and sanitizers and better understanding of factors contributing to the spread of this airborne virus in local environment.

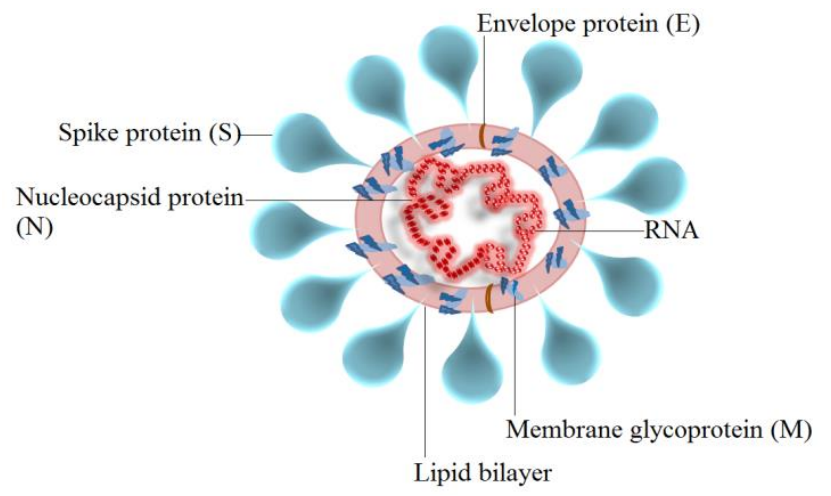

Fig. 1. Structure of SARS_CoV-2 causing novel coronavirus disease 2019.

\section{ROLE OF ENVIRONMENT IN SPREAD OF COVID-19}

A. Tobacco and E-cigarettes in Transmission of SARS-CoV2

In order to reduce the spread of infectious SARS-CoV-2, a major part of world was under lockdown. This increased the indoor use of electronic cigarette as well as combustible tobacco which can possibly increase the transmission rates of COVID-19 [40]. In line to this, the role of Dhoopan in prevention of airborne SARS-CoV-2 infections was reported. This includes inhalation/exposure to fumes or smoke produced from drug formulations for therapeutic relief externally or as environmental cleanser [41].The infection transmits from the carrier person through aerosols generated from electronic cigarettes and smoke from combustible tobacco respectively, finally passing the infection to the most high-risk groups i.e., older people or people with comorbidities [42] and children [43], [44].The viral laden droplets from an infected person contaminate the air and get transmitted finally to a larger group in the surrounding [24], [45], [46]. In addition to this, dust particles, smoke or aerosols already present in the atmosphere can adsorb coronavirus becoming infective at later stages [40], [47], [48]. Often these adsorbed viruses on airborne dust support long-range transfer of viruses [49].Therefore, there is an urgent need to emphasize on the role of transmission of coronavirus through aerosols or smoke generated from cigarettes or tobacco [40]. Keeping in view the risk and critical pandemic condition of the world, most of the Indian states banned the use of tobacco and pan gutkha.

\section{B. Role of Wastewater in Transmission of SARS-CoV-2}

There are several reports regarding presence of SARSCoV-2 in wastewater [50]. Analysis of wastewater samples collected from different countries such as Australia, USA, France etc. [51]-[54]showed presence of virus suggesting contamination through human sewage. The report by Ahmed et al. suggested that untreated wastewater samples from Australia (Brisbane, Queensland) had viral RNA concentration of $1.2 \times 10^{2}$ copies/ L of SARS-CoV-2 [51]. In addition to this, reports by two independent groups in USA showed $2 \times 10^{5}$ copies/L [52] and $3 \times 10^{4}$ copies/L [53] of SARS-CoV-2 RNA in untreated wastewater samples collected from Massachusetts and Montana area, respectively. Study by Wurtzer et al. in 2020 found similar concentrations of SARS-CoV-2 both in treated as well as untreated wastewater samples from France (Paris) was less than $10^{6.5}$ copies/Land near about $10^{5}$ copies/L respectively [54]. The testing and surveillance on wastewater transmission of SARS-CoV-2 in various regions of the world is still a subject of concern. The knowledge of potential role of wastewater in transmission of SARS-CoV-2 revolves around its origin, concentration, and removal of the virus in wastewater by different methods. This generates a need for continuous risk assessment and enthusiastic research for control and monitoring on viral detection and prevention of wastewater transmission in infected areas particularly the high-risk areas.

\section{Role of Faecal Matter in Transmission of SARS-CoV-2}

The possible faecal transmission of SARS-CoV-2 is a matter of concern for public health and environment [55].A number of studies revealed that SARS-CoV-2 are present in faecal material of the patients or that the virus can spread through faecal transmission [56]-[61].The article by Wang et al. identified high numbers of viral RNA copy in stool samples of four patients and observed live virus in two of them using electron microscopy [56].However, the studies on factors like frequency of viable virus in stool of patient or the range of viral loads in stool of the patient is required to evaluate the transmission possibility of virus through faecal material or the capability of the virus to spread through stool or faecal transmission. In addition to this even a low infective viral load in stool draws attention for research concerning faecal transmission [62]. The report by Xiao et al. showed SARS-CoV-2 RNA in 53\% of faecal samples from hospitalized patients. Moreover, 23\% isolation was seen for those patients in whom respiratory tract infection had disappeared [58]. Recent studies showed that the concentration of viral RNA extends up to $10^{8}$ copies per gram of faeces [62]-[65]. Some findings also revealed SARS-CoV-2 RNA presence in faeces for up to seven weeks after first symptomatic start [66], [67]. There are also reported studies for SARS-CoV-2 RNA detections in the faeces of asymptomatic individuals [68]. These postulations still require confirmed studies and raises potential urge to investigate critically the sensitive matter of faecal transmission of virus.

\section{Role of Fomites in Transmission and Human-to-Human Transmission of SARS-CoV-2}

The role of fomites i.e., inanimate objects such as clothes, doorknobs, utensils, polythenes and other surfaces in transmission of infectious CoV-2 is important to understand as the virus sustains on the surfaces for several days [69], [49]. The deadliest side of infectious CoV-2 is human-tohuman transmission which has made the current scenario unhealthy and sorrowful for humanity and environment [70]-[72]. The role of various environmental factors in transmission of SARS-CoV-2 is shown in Fig. 2. 


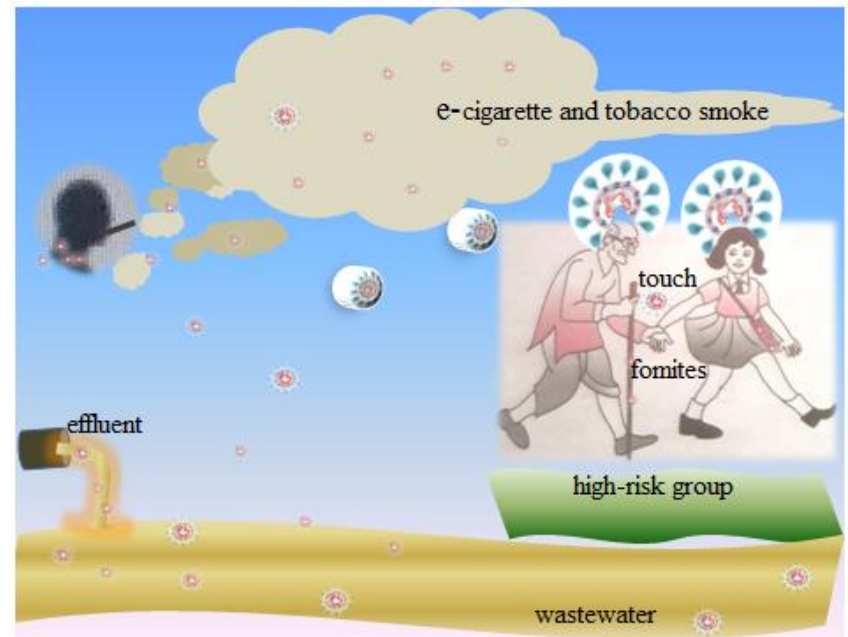

Fig. 2. Environmental transmission of SARS-CoV-2.

\section{THERAPEUTICS}

\section{A. Potential Therapeutic Drugs for COVID-19}

Coronavirus outbreak has challenged the health globally. The pandemic disease is a new outburst and requires a vigorous case study in terms of its origin, effects, and treatment. Currently, there is neither specific antiviral treatment nor vaccination treatment against the pandemic COVID-19. Though vaccination trials and diagnosis are being investigated at the utmost level, but still, it's a time taking process and needs an expedited research in medical field. There are several other known therapeutic drugs which were used against MERS-CoV, Ebola virus and other infectious viral diseases are now being tested against SARSCoV-2 for their efficiency in Covid-19 patients all over the world [73], [74]. Some of these drugs along with their mode of action on target virus are discussed in brief (Table 1).

\section{B. Remdesivir}

The mechanism of action of already existing anti-viral drug remdesivir includes inhibition of RNA dependent RNA polymerase. The therapeutic role of remdesivir (used for Ebola treatment) has proved effective in treatment against COVID -19 patients in US and other parts of the world [75][77].In a recent clinical trial, remdesivir was administered to 53 COVID-19 patients who were on oxygen support or mechanical ventilation due to an oxygen saturation of $94 \%$ suggested that intravenous administration with $200 \mathrm{mg}$ remdesivir at day 1 , followed by $100 \mathrm{mg}$ daily for 9 days, resulted in medical improvement in $68 \%$ of the patients $(36$ out of 53) [78].Though the mortality rate was $18 \%$ among patients on invasive ventilation while $5 \%$ among those not acquiring invasive ventilation. This finding suggested remdesivir comprises a potential therapeutic option for COVID-19 patients not obtaining invasive ventilation [77]. Since there is no specific therapeutic treatment till date for the deadly infectious SARS-CoV-2, this drug seems to be a potential alternative to combat COVID-19 cases and the clinical trials are ongoing studies.

\section{Favipiravir (Avigan ${ }^{T M}$ )}

Another therapeutic agent acting as inhibitor of RNAdependent RNA polymerase is favipiravir which showed effectiveness in treatment of SARS-CoV-2 patients in China [78], [73]. Recently, results of clinical diagnosis in treatment of Chinese patients infected with SARS-CoV-2 showed good efficacy of favipiravir which enquired the need for randomised clinical trials and confirmed studies [78].

\section{Lopinavir/Ritonavir (kaletra ${ }^{T M}$ )}

The already known antiviral drug Lopinavir/ Ritonavir (used for HIV treatment) acts as the inhibitor of papain-like protease and 3C-like protease is being tested against SARSCoV-2 [79], [74]. A recent random trial was done on adult COVID-19 patients in China. The results were disappointing in terms of reduction in viral RNA loads or duration of viral detectability. However, the numbers of recipients (Lopinavir/ Ritonavir) who have comorbidities or requiring ventilation were less as compared to those who have not received Lopinavir/ Ritonavir [79]. Hence, the studies for its efficacy to reduce severity in COVID-19 patients with some comorbidity are on-going research. Also, the combinations of Lopinavir/ Ritonavir plus interferon beta-1a (used to treat multiple sclerosis) are under clinical trials over COVID-19 patients [80].

\section{E. Chloroquine Phosphate and Hydroxychloroquine}

The potential antimalarial drug Chloroquine phosphate which acts as the inhibitor of endosomal acidification is recently tested over more than 100 patients infected with COVID-19 disease in China [81]. The results were positive and showed improvement in complications of pneumonia along with shortening the course of novel coronavirus disease. These findings demanded the clinical trials for chloroquine phosphate to treat COVID-19 associated pneumonia cases [81], [82].Hydroxychloroquine is also recommended to treat COVID-19 patients which controls the cytokine storm occurring in severely ill SARS-CoV-2 patients at later phase of infection [83].In one recent study, azithromycin $(500 \mathrm{mg}$ on day 1 , followed by $250 \mathrm{mg}$ per day on day 2-5) was shown to appreciably enhance the antiSARS-CoV-2 activity of hydroxychloroquine (200 mg three times per day for 10 days) in the treatment of 20 patients critically ill with COVID-19 infection. Thus the finding suggested the clinical outcome of these patients was the result of this combination therapy [84].In a recent clinical trial conducted in Wuhan, China in Feb 2020, 62 COVID-19 patients were arbitrary administered with either daily 400 $\mathrm{mg}$ hydroxychloroquine for 5 days $(n=31)$ or no pharmacological treatment $(n=31)$ [85].The observations included improvement and absorption of pneumonia at day 6 in $80.6 \%$ of the recipients (hydroxychloroquine treated) while it was $54.8 \%$ in the untreated cases [85].

\section{F. Phytochemicals}

There are several medicinal plants from which potential phytochemicals were isolated for antiviral treatment of SARS-CoV-2 [86]. The isolated phytochemicals are traditional Chinese medicinal compounds that act against the virus by enzyme inhibition action responsible for replication 
and life cycle of the virus. Among several natural plant medicines there are few top phytochemicals that can serve as highly effective anti SARS-CoV-2 molecules for drug discovery and treatment of COVID-19. These includes myricitrin, methyl rosmarinate, licoleafol, amaranthin, calceolarioside, etc with their plant sources as Myricacerifera, HyptisatrorubensPoit, Glycyrrhizauralensis, Amaranthustricolor, Fraxinussieboldiana respectively [86].Some of these phytochemicals like 6 - $\alpha$-acetoxygedunin and echitamine can play dominant role in drug development against SARS-CoV-2 [87].However, these considerations require large-scale diagnosis and proper clinical analysis for claiming confirmatory role in control and prevention of COVID-19 pandemic.

TABLE I: Potential Therapeutic AgEnts AgAinst SARS-COV-2 DISEASE AND THEIR MECHANISM OF ACTION

\begin{tabular}{|c|c|c|}
\hline Drugs & Mechanism of action & References \\
\hline Remdesivir & $\begin{array}{c}\text { Inhibition of the RNA- } \\
\text { dependent RNA } \\
\text { polymerase, Antiviral drug }\end{array}$ & {$[75]$} \\
\hline Favipiravir (Avigan ${ }^{\mathrm{TM}}$ ) & $\begin{array}{c}\text { Inhibition of the RNA- } \\
\text { dependent RNA } \\
\text { polymerase, Antiviral drug }\end{array}$ & [78] \\
\hline $\begin{array}{l}\text { Lopinavir/ritonavir } \\
\quad\left(\text { kaletra }^{\mathrm{TM}}\right)\end{array}$ & $\begin{array}{l}\text { Inhibition of papain-like } \\
\text { protease and 3C-like } \\
\text { protease, Antiviral drug }\end{array}$ & [79] \\
\hline $\begin{array}{l}\text { Chloroquine phosphate } \\
\quad\left(\operatorname{Resochin}^{\mathrm{TM}}\right)\end{array}$ & $\begin{array}{c}\text { Inhibition of endosomal } \\
\text { acidification (early } \\
\text { endosomal pathway), } \\
\text { Antimalarial drug }\end{array}$ & $\begin{array}{c}{[81],[82],} \\
{[76]}\end{array}$ \\
\hline $\begin{array}{c}\text { Hydroxychloroquine } \\
\text { (Quensil }^{\mathrm{TM}}, \text { Plaquenil }^{\mathrm{TM}}, \\
\text { Hydroquin }^{\mathrm{TM}}, \text { Dolquin }^{\mathrm{TM}} \text {, } \\
\text { Quinoric }^{\mathrm{TM}} \text { ) }\end{array}$ & $\begin{array}{l}\text { Inhibition of endosomal } \\
\text { acidification (early } \\
\text { endosomal pathway) (also } \\
\text { azithromycin is reported to } \\
\text { greatly enhance the anti- } \\
\text { SARS-CoV-2 activity of } \\
\text { hydroxychloroquine), } \\
\text { Antimalarial drug }\end{array}$ & {$[82]-[85]$} \\
\hline
\end{tabular}

\section{G. Convalescent Plasma}

There is no specific treatment till date for SARS-CoV-2 responsible for COVID-19 pandemic. The use of various potential therapeutic drugs is on-going studies. In this present situation of darkness, a glimpse of light of hope emerges in the form of convalescent plasma therapy. This therapy constitutes the administration of immunoglobulin antibodies taken from the plasma of patients recovered from COVID-19 into critical patients of COVID-19. The proposed mechanism of action of the above therapy includes direct neutralization of SARS-CoV-2, control, and coordination of super-active response of immune system and immunomodulation [88]. The report by Shen et al. described the treatment of five critically ill patients of COVID-19 disease who recovered after treatment with plasma therapy. The plasma along with antiviral agents was administered to five critically ill hospitalized patients. After transfusions, improvements in their health condition were noticed with decline in viral loads. Moreover, three patients out of five were discharged after a stay of 51 to 55 days while two were in stable condition after 37 days from transfusion [89]. These findings suggested the convalescent plasma therapy can be used as an effective tool in terms of reducing mortality or fighting morbidity against COVID-19 but is limited by a small number of successful studies which still requires a large-scale study and clinical data analysis.

\section{SAFETY MEASURES}

Since there is no specific treatment against the virus, we need rely on safety measures that could possibly reduce infection and mortality. The wheel of safety measures rotates on prevention and precaution.

\section{A. Prevention}

The preventive measures should be assured for to stop the spread of novel coronavirus. These include isolation of suspected cases and quarantining their close contacts. There should be complete isolation of confirmed cases in single room in hospitals. Essential wearing of PPE for Medical persons should be implemented at all levels of health sector. Proper disinfection of rooms after discharge of COVID-19 patients in all the quarantine centres as well as hospitals must be ensured. Sealing and quarantining of hotspot areas is needed. Implementation of thermal screening of citizens boarding from hotspot areas is a must.

\section{B. Precaution}

The areas that remained free from infection should ensure proper precaution measures to maintain themselves in the green zones. This requires improvement in surveillance systems. Following are some to do list:

(i) Avoid large-scale community gathering.

(ii) Enforcement of strict actions against violation of social distancing in public places.

(iii) Regular sanitization and awareness on personal and community hygiene.

(iv) Wearing face masks and hand hygiene is mandatory.

(v) Proper investment to build up proper health care facilities for early response towards a pandemic outbreak.

The three aspects of safety to deal the pandemic are shown in Fig. 3.

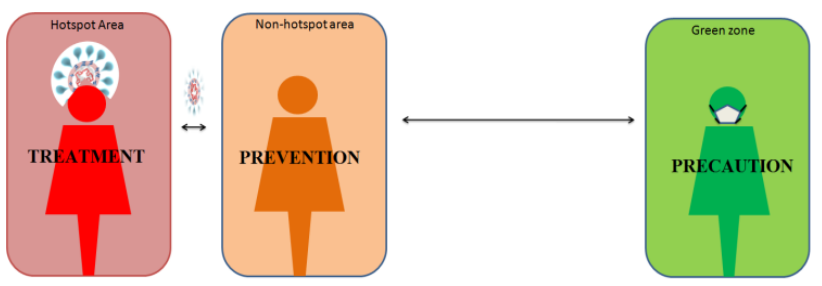

Fig. 3. Three aspects of safety measure to combat COVID-19.

\section{IMPLICATIONS}

The current situation is a global health threat caused due to COVID-19 pandemic. This article organizes all the arbitrary information on biochemistry, environmental spread, and safety measures on SARS-CoV-2 in a single package. The fight against the novel CoV-2 is a challenge and the world is struggling hard to face it. Therefore, it becomes mandatory to understand the nature and biochemistry of the virus that would help directly in drug discovery and vaccination. Moreover, the chain of 
transmission and the environmental factors responsible for spread should be exercised on a serious note to stop the infection globally. The role of contaminated wastewater, aerosols (viral-laden smoke from cigarettes and tobacco), faecal matter, fomites in spread and human to human transmission of SARS-CoV-2 is a matter of global concern and requires rigorous case study. As of now there is no specific antiviral agent against the new novel coronavirus, though remdesivir seems to be an effective alternative against $\mathrm{CoV}-2$. There are some other potential drugs under clinical trials against the novel coronavirus. Phytochemicals and plasma therapy are limited by a small number of successful cases. Social distancing, personal hygiene and community hygiene are the only possible prevention to combat COVID-19 disease. This review highly appreciates the tremendous contribution of all the researchers to bring forth all the information regarding SARS-CoV-2 and is still continuing to do so. We also hope for the betterment of the present situation and believe soon the dark days will come to an end with new glories and happiness.

\section{ABBREVIATIONS USED}

WHO, World Health Organization; SARS-CoV-2, Severe acute respiratory syndrome coronavirus-2; COVID-19, coronavirus disease 2019; $\mathrm{CoV}$, coronavirus; SARS, severe acute respiratory syndrome; SARS-CoV, severe acute respiratory syndrome coronavirus; MERS, Middle East respiratory syndrome; MERS-CoV, Middle East respiratory syndrome coronavirus; ACE2, angiotensin-converting enzyme 2;HCoV-229E, Human coronavirus HCOV229E;HCoV-NL63, Human coronavirus HCOVNL63;HCoV-OC43, Human coronavirus HCOVOC43;HCoV-HKU1,Human coronavirus HCOV-HKU1.

\section{AUTHORSHIP CONTRIBUTION STATEMENT}

Roshni Kumari and Kumari Pragati Nanda - Contributed Equally to drafting the manuscript. Soumen Dey and Hena Firdaus supervised the work.

\section{ACKNOWLEDGMENT}

The authors acknowledge all the researchers who bring forth the valuable research information and are continuing to do so to overcome this pandemic.

\section{REFERENCES}

[1] Tu, H., Tu, S., Gao, S., Shao, A. and Sheng, J. (2020) The epidemiological and clinical features of COVID-19 and lessons from this global infectious public health event. J. Infect. DOI: 10.1016/j.jinf.2020.04.011.

[2] Xu, J., Shi, P.-Y., Li, H. and Zhou, J. (2020) Broad Spectrum Antiviral Agent Niclosamide and Therapeutic Potential. ACS Infect. Dis. DOI: 10.1021/acsinfecdis.0c00052.

[3] Kang, S., Peng, W., Zhu, Y., Lu S., Zhou, M., Lin, W., Wu, W., Huang, S., Jiang, L., Luo, X., Deng, M. (2020) Recent progress in understanding 2019 novel coronavirus (SARS-CoV-2) associated with human respiratory disease: detection, mechanisms and treatment. Int. J. Antimicrob. Agents. DOI: 10.1016/j.ijantimicag.2020.105950.

[4] Chang, L., Yan, Y. and Wang, L. (2020) Coronavirus Disease 2019: Coronaviruses and Blood Safety. Transfus. Med. Rev. 34, 75-80.

[5] Singh, A., Shaikh, A., Singh, R. and Singh, A. K. (2020) COVID-19: From bench to bed side. Diabetes Metab. Syndr. 14, 277-281.

[6] Woo, P.C., Lau, S. K., Lam, C. S., Lau, C. C., Tsang, A. K., Lau, J. H., Bai, R., Teng, J. L., Tsang, C. C., Wang, M., Zheng, B. J., Chan, K. H., Yuen, K. Y. (2012) Discovery of seven novel Mammalian and avian coronaviruses in the genus deltacoronavirus supports bat coronaviruses as the gene source of alphacoronavirus and betacoronavirus and avian coronaviruses as the gene source of gammacoronavirus and deltacoronavirus. J. Virol. 86, 3995-4008.

[7] Rahimi, F. and Abadi, A. T. B. (2020) Tackling the COVID-19 Pandemic. Archives of Medical Research. DOI 10.1016/j.arcmed.2020.04.012.

[8] Delgado-Roche, L. and Mesta F. (2020) Oxidative Stress as Key Player in Severe Acute Respiratory Syndrome (SARS-CoV) Infection. Arch. Med. Res. DOI: 10.1016/j.arcmed.2020.04.019.

[9] Wong, M. C., Cregeen, S. J. J., Ajami, N. J., Petrosino, J. F. (2020) Evidence of recombination in coronaviruses implicating pangolin origins of nCoV-2019. bioRxiv. DOI: 10.1101/2020.02.07.939207.

[10] Xiao, K., Zhai, J., Feng, Y., Zhou, N., Zhang, X., Zou, J. J., Li, N., Guo, Y., Li, X., Shen, X., Zhang, Z., Shu, F., Huang, W., Li, Y., Zhang, Z., Chen, R. A., Wu, Y. J., Peng, S. M., Huang, M., Xie, W J., Cai, Q. H., Hou, F. H., Liu, Y., Chen, W., Xiao, L., Shen, Y. (2020) Isolation and Characterization of 2019-nCoV-like Coronavirus from Malayan Pangolins. bioRxiv. DOI: $10.1101 / 2020.02 .17 .951335$

[11] Lam, T. T.Y., Shum, M. H. H., Zhu, H. C., Tong, Y. G., Ni, X. B. Liao, Y. S., Wei, W., Cheung, W. Y. M., Li, W. J., Li, L. F., Leung, G. M., Holmes, E. C., Hu, Y. L., Guan, Y. (2020) Identification of 2019-nCoV related coronaviruses in Malayan pangolins in southern China. bioRxiv. DOI: 10.1101/2020.02.13.945485.

[12] Tang, X., Wu, C., Li, X., Song, Y., Yao, X., Wu, X., Duan, Y., Zhang, H., Wang, Y., Qian, Z., Cui, J., Lu, J. (2020) On the origin and continuing evolution of SARS-CoV-2. Natl. Sci. Rev. 7, 1012 1023.

[13] Wang, Z., Yang, B., Li, Q., Wen, L. and Zhang, R. (2020) Clinical Features of 69 Cases with Coronavirus Disease 2019 in Wuhan, China. Clin. Infect. Dis. DOI: 10.1093/cid/ciaa272.

[14] Peeri, N. C., Shrestha, N., Rahman, M. S., Zaki, R., Tan, Z., Bibi, S., Baghbanzadeh, M., Aghamohammadi, N., Zhang, W., Haque, U. (2020) The SARS, MERS and novel coronavirus (COVID-19) epidemics, the newest and biggest global health threats: what lessons have we learned? Int J Epidemiol. DOI:10.1093/ije/dyaa033.

[15] Lu, R., Zhao, X., Li, J., Niu, P., Yang, B., Wu, H., Wang, W., Song, H., Huang, B., Zhu, N., Bi, Y., Ma, X., Zhan, F., Wang, L., Hu, T., Zhou, H., Hu, Z., Zhou, W., Zhao, L., Chen, J., Meng, Y., Wang, J., Lin, Y., Yuan, J., Xie, Z., Ma, J., Liu, W. J., Wang, D., Xu, W., Holmes, E. C., Gao, G. F., Wu, G., Chen, W., Shi, W., Tan, W. (2020) Genomic characterisation and epidemiology of 2019 novel coronavirus: implications for virus origins and receptor binding. Lancet 395, 565-74.

[16] Zhou, P., Yang, X. -L., Wang, X. -G., Hu, B., Zhang, L., Zhang, W., Si, H. R., Zhu, Y., Li, B., Huang, C. L., Chen, H. D., Chen, J., Luo, Y., Guo, H., Jiang, R. D., Liu, M. Q., Chen, Y., Shen, X. R., Wang, X., Zheng, X. S., Zhao, K., Chen, Q. J., Deng, F., Liu, L. L. Yan, B., Zhan, F. X., Wang, Y. Y., Xiao, G., Shi, Z. L.(2020) Discovery of a novel coronavirus associated with the recent pneumonia outbreak in humans and its potential bat origin. bioRxiv. DOI: $10.1038 / \mathrm{s} 41586-020-2012-7$

[17] Li, W., Shi, Z., Yu, M., Ren, W., Smith, C., Epstein J. H., Wang, H., Gary, C., Hu, Z., Zhang, H., Zhang, J., McEachern, J., Field, H., Daszak, P., Eaton, B. T., Zhang, S., Wang, L. F. (2005) Bats Are Natural Reservoirs of SARS-Like Coronaviruses. Science. 310, 676679.

[18] Gralinski, L. E. and Menachery V. D. (2020) Return of the Coronavirus: 2019-nCoV. Viruses. DOI:10.3390/v12020135.

[19] Paraskevis, D., Kostakis, E. G., Magiorkinis, G., Panayiotakopoulos G., Sourvinos, G., Tsiodras S. (2020) Full-genome evolutionary analysis of the novel corona virus $(2019-n \mathrm{CoV})$ rejects the hypothesis of emergence as a result of a recent recombination event. Infect. Genet. Evol. DOI: 10.1016/j.meegid.2020.104212.

[20] Masters, P. S., (2006) The molecular biology of coronaviruses. $A d v$ Virus Res. 66, 193-292.

[21] Schoeman, D. and Fielding, B. C. (2019) Coronavirus envelope protein: current knowledge. Virol. J. 16, 1-22. 
[22] Siu, Y., Teoh, K., Lo, J., Chan, C., Kien, F., Escriou, N., Tsao, S. W., Nicholls, J. M., Altmeyer, R., Peiris, J. S. M., Bruzzone, R., Nal B. (2008) The M, E, and N structural proteins of the severe acute respiratory syndrome coronavirus are required for efficient assembly, trafficking, and release of virus-like particles. J. Virol.82, 1131811330.

[23] Kirchdoerfer, R. N., Cottrell, C. A., Wang, N., Pallesen, J., Yassine, H. M., Turner, H. L., Corbett, K. S., Graham, B. S., McLellan, J. S., Ward, A. B. (2016) Pre-fusion structure of a human coronavirus spike protein. Nature. 531, 118-21.

[24] Fehr, A. R. and Perlman, S. (2015) Coronaviruses: An overview of their replication and pathogenesis. Coronaviruses 1282, 1-23.

[25] Millet, J. K. and Whittaker, G. R. (2015) Host cell proteases: Critical determinants of coronavirus tropism and pathogenesis. Virus Res. 202, 120-134

[26] deHaan, C. A. andRottier, P. J. (2005) Molecular interactions in the assembly of coronaviruses. Adv. Virus Res. 64, 165-230.

[27] Boscarino, J. A., Logan, H. L., Lacny, J. J., and Gallagher, T. M. (2008) Envelope protein palmitoylations are crucial for murine coronavirus assembly. J. Virol.82, 2989-2999.

[28] Venkatagopalan, P., Daskalova, S. M., Lopez, L. A., Dolezal, K. A. Hogue, B. G. (2015) Coronavirus envelope (E) protein remains at the site of assembly. Virology. 478, 75-85.

[29] Snijder, E. J., Bredenbeek, P. J., Dobbe, J. C., Thiel, V., Ziebuhr, J., Poon, L. L. M., Guan, Y., Rozanov, M., Spaan, W. J. M. Gorbalenya, A. E. (2003) Unique and conserved features of genome and proteome of SARS-coronavirus, an early split-off from the coronavirus group 2 lineage. J. Mol. Biol. 331, 991-1004.

[30] Hussain S., Pan, J., Chen, Y., Yang, Y. and Xu, J., Peng, Y., Wu, Y., Li, Z., Zhu, Y., Tien, P., Guo, D. (2005) Identification of novel subgenomic RNAs and noncanonical transcription initiation signals of severe acute respiratory syndrome coronavirus. J. Virol. 79, 52885295.

[31] Chen, Y., Su, C., Ke, M., Jin, X., Zhang, Z., Wu, A., Sun, Y., Yang, Z., Tien, P., Ahola, T., Liang, Y., Liu, X., Guo, D. (2011) Biochemical and Structural Insights into the Mechanisms of SARS Coronavirus RNA Ribose 2'-O-Methylation by nsp16/nsp10 Protein Complex. PLOS Pathogens. e1002294. DOI 10.1371/journal.ppat.1002294

[32] Li, X., Geng, M., Peng, Y., Meng, L. and Lu, S. (2020) Molecular immune pathogenesis and diagnosis of COVID-19. J. Pharm. Anal. 10, 102-108.

[33] Knoops, K., Kikkert, M., Worm, S. H., Zevenhoven-Dobbe, J. C. van der Meer, Y., Koster, A. J., Mommaas, M., Snijder, E. J. (2008) SARS-coronavirus replication is supported by a reticulovesicula network of modified endoplasmic reticulum. PLOS Biol. 6, e226. DOI: 10.1271/journal.pbio.0060226.

[34] Chen, Y., Cai, H., Pan, J., Xiang, N., Tien, P., Ahola, T. and Guo, D. (2008) Functional screen reveals SARS coronavirus nonstructura protein nsp14 as a novel cap N7 methyltransferase. Proc. Natl. Acad. Sci. U.S.A 106, 3484-3489.

[35] Minskaia, E., Hertzig, T., Gorbalenya, A. E., Campanacci, V. R. Cambillau, C., Canard, B. and Ziebuhr, J. (2006) Discovery of an RNA virus 3_35_ exoribonuclease that is critically involved in coronavirus RNA synthesis. Proc. Natl. Acad. Sci. U.S.A. 1034 5108-5113.

[36] Tang, J. W. (2009) The effect of environmental parameters on the survival of airborne infectious agents. J. R. Soc. Interface. 6 Supp 6(Suppl 6), S737-S746. DOI: 10.1098/rsif.2009.0227.focus.

[37] Rabenau, H. F., Cinatl, J., Morgenstern, B., Bauer, G., Preiser, W. and Doerr, H. W. (2005) Stability and inactivation of SARS coronavirus. Med. Microbiol. Immun. 194, 1-6.

[38] Bamola, V. D., and Chaudhry, R. (2020) Recent Discovery and Development on SARS-CoV-2: A Review of Current Literature. DOI: $10.31219 /$ osf.io/8gq3j

[39] Geller, C., Varbanov, M. and Duval, R. E. (2012) Human coronaviruses: insights into environmental resistance and its influence on the development of new antiseptic strategies. Viruses. 4, 3044-3068.

[40] Mahabee-Gittens, M. E., Merianos, A. L., and Matt, G. E. (2020) Letter to the Editor Regarding: "An Imperative Need for Research on the Role of Environmental Factors in Transmission of Novel Coronavirus (COVID-19)" - Secondhand and Thirdhand Smoke as Potential Sources of COVID-19. Environ. Sci. Technol. 54, 53095310.

[41] Rathi, B., Rathi, B. J., Bhutada, R. S., Dasar, D., Khatana, R. (2020) Review on role of Dhoopan in the prevention of airborne infections (COVID-19). Int. J. Pharm. Sci. 11, 246-252.
[42] Zhou, F., Yu, T., Du, R et al. (2020) Clinical course and risk factor for mortality of adult inpatients with COVID-19 in Wuhan, China: a retrospective cohort study. Lancet 395, 1054-1062.

[43] Mahabee-Gittens, E. M., Merianos, A. L., Matt, G. E. (2017) Preliminary evidence that high levels of nicotine on children's hands may contribute to overall tobacco smoke exposure. Tob. Control 27 , 217-219.

[44] Cruz, A., Zeichner, S. (2020) COVID-19 in children: Initial characterisation of the pediatric disease. Pediatrics e20200834.

[45] Mulder, H. A., Patterson, J. L., Halquist, M. S., Kosmider, L., Turner, Mc. J. B., Poklis, J. L., Poklis, A., Peace, M. R. (2019) The Effect of Electronic Cigarette User Modifications and E-liquid Adulteration on the Particle Size Profile of an Aerosolized Product. Sci. Rep. DOI: 10.1038/s41598-019-463872.

[46] Bourouiba, L. (2020) Turbulent Gas Clouds and Respiratory Pathogen Emissions: Potential Implications for Reducing Transmission of COVID 19. J. Am. Med. Assoc. DOI: 10.1001/jama.2020.4756

[47] van Doremalen, N., Bushmaker, T., Morris, D. H., Holbrook, M. G., Gamble, A., Williamson, B. N., Tamin, A., Harcourt, J. L., Thornburg, N. J., Gerber, S. I., Lloyd-Smith, J. O., de Wit, E. Munster, V. J. (2020) Aerosol and Surface Stability of SARS-CoV-2 as Compared with SARS-CoV-1. N. Engl. J. Med. 382, 1564-1567.

[48] Becquemin, M. H., Bertholon, J. F., Bentayeb, M., Attoui, M., Ledur, D., Roy, F., Roy, M., Annesi-Maesano, I., Dautzenberg, B. (2010) Thirdhand smoking: indoor measurements of concentration and sizes of cigarette smoke particles after resuspension. Tob. Control 19, 347-348.

[49] Qu, G., Li, X., Hu, L., and Jiang, G. (2020) An Imperative Need for Research on the Role of Environmental Factors in Transmission of Novel Coronavirus (COVID-19). Environ. Sci. Technol. 54, 3730-3732.

[50] Kitajima, M., Ahmed, W., Bibby, K., Carducci, A., Charles P., Gerba, K. A., Hamilton, E. H., Joan, B. R. (2020) SARS-CoV-2 in wastewater: State of the knowledge and research needs. Sci. Total Environ. DOI: 10.1016/j.scitotenv.2020.139076.

[51] Ahmed, W., Angel, N., Edson, J., Bibby, K., Bivins, A., Brien, J.W.O., Choi, P.M., Kitajima, M., Simpson, S.L., Li, J., Tscharke, B., Verhagen, R., Smith, W.J.M., Zaugg, J., Dierens, L., Hugenholtz, P., Thomas, K. V, Mueller, J. F. (2020) First confirmed detection of SARS-CoV-2 in untreated wastewater in Australia: A proof of concept for the wastewater surveillance of COVID-19in the community. Sci. Total Environ. DOI: 10.1016/j.scitotenv.2020.138764

[52] Wu, F., Xiao, A., Zhang, J., Gu, X., Lee, W., Kauffman, K., Hanage, W., Matus, M., Ghaeli, N., Endo, N., Duvallet, C., Moniz, K., Erickson, T., Chai, P., Thompson, J., Alm, E. L. (2020) SARS-CoV2 titers in wastewater are higher than expected from clinically confirmed cases. medRxiv. DOI: 10.1101/2020.04.05.20051540

[53] Nemudryi, A., Nemudraia, A., Surya, K., Wiegand, T., Buyukyoruk, M., Wilkinson, R., Wiedenheft, B. (2020) Temporal detection and phylogenetic assessment of SARS-CoV-2 in municipal wastewater. medRxiv. DOI: 10.1101/2020.04.15.20066746.

[54] Wurtzer, S., Marechal, V., Mouchel, J., Moulin, L. (2020) Time course quantitative detection of SARSCoV- 2 in Parisian wastewaters correlates with COVID-19 confirmed cases. medRxiv. DOI: $10.1101 / 2020.04 .12 .20062679$.

[55] Amirian, E. S. (2020) Potential Fecal Transmission of SARS-CoV-2 Current Evidence and Implications for Public Health. Int. J. Infect. Dis. 95, 363-370

[56] Wang, W., Xu, Y., Gao, R., Lu, R., Han, K., Wu, G., Tan, W. (2020) Detection of SARS-CoV-2 in Different Types of Clinical Specimens. J. Am. Med. Assoc. 323, 1843-1844.

[57] Zhang, J., Wang, S., Xue, Y. (2020) Fecal specimen diagnosis 2019 novel coronavirus-infected pneumonia. J. Med. Virol. DOI 10.1002/jmv. 25742

[58] Xiao, F., Tang, M., Zheng, X., Liu, Y., Li, X., Shan, H. (2020) Evidence for gastrointestinal infection of SARS-CoV-2. Gastroenterology, DOI: 10.1101/2020.02.17.20023721.

[59] Zhang, Y., Chen, C., Zhu, S., Shu, C., Wang, D., Song, J., Song, Y., Zhen, W., Feng, Z., Wu, G., Xu, J., Xu, W. (2020) Isolation of 2019nCoV from a Stool Specimen of a Laboratory-Confirmed Case of the Coronavirus Disease 2019 (COVID-19). China CDC Weekly. DOI: $10.46234 / \mathrm{ccdcw} 2020.033$

[60] Gu, J., Han, B., Wang, J. (2020). COVID-19: Gastrointestinal manifestations and potential fecal-oral transmission. Gastroenterology. DOI: 10.1053/j.gastro.2020.02.054. 
[61] Song, Y., Liu, P., Shi, X. L., Chu, Y. L, Zhang, J., Xia, J., Gao, X Z., Qu, T., Wang, M. Y. (2020) SARS-CoV-2induced diarrhoea as onset symptom in patient with COVID-19. Gut 69, 1143-1144, DOI: 10.1136/gutjnl-2020-320891.

[62] Lee, P. I., Hsueh, P. R. (2020) Emerging threats from zoonotic coronaviruses-from SARS and MERS to 2019-nCoV. J Microbiol. Immunol. Infect. 53, 365-367.

[63] Lescure, F. X., Bouadma, L., Nguyen, D., Parisey, M., Wicky, P. H., Behillil, S., Gaymard, A., Bouscambert-Duchamp, M., Donati, F., Le Hingrat, Q., Enouf, V., Houhou-Fidouh, N., Valette, M., Mailles, A., Lucet, J. C., Mentre, F., Duval, X., Descamps, D., Malvy, D., Timsit, J. F., Lina, B., van-der-Werf, S., Yazdanpanah, Y. (2020)Clinical and virological data of the first cases of COVID-19 in Europe: a case series. Lancet Infect. Dis. 2, 1-10.

[64] Pan, Y., Zhang, D., Yang, P., Poon, L.L.M., Wang, Q. (2020) Viral load of SARS-CoV-2 in clinical samples. Lancet Infect. Dis. 20, 411-412.

[65] Wolfel, R., Corman, V. M., Guggemos, W., Seilmaier, M., Zange, S., Mueller, M.A., Niemeyer, D., Vollmar, P., Rothe, C., Hoelscher, M., Bleicker, T., Bruenink, S., Schneider, J., Ehmann, R., Zwirglmaier, K., Drosten, C., Wendtner, C. (2020) Virological assessment of hospitalized cases of coronavirus disease 2019 Nature. DOI: 10.1038/s41586-020-2196-x.

[66] Jiehao, C., Jing, X., Daojiong, L., Lei, X., Zhenghai, Q., Yuehua, Z., Hua, Z., Xiangshi, W., Yanling, G., Aimei, X., He, T., Hailing, C., Chuning, W., Jingjing, L., Jianshe, W., Mei, Z., Children, N., Women, H., Central, S., Zeng, M. (2020) A case series of children with 2019 novel coronavirus infection: clinical and epidemiological features. Clin. Infect. Dis. DOI: 10.1093/cid/ciaa198.

[67] Wu, Y., Guo, C., Tang, L., Hong, Z., Zhou, J., Dong, X., Yin, H., Xiao, Q., Tang, Y., Qu, X., Kuang, L., Fang, X., Mishra, N., Lu, J., Shan, H., Jiang, G., Huang, X. (2020) Prolonged presence of SARS CoV- 2 viral RNA in faecal samples. Lancet Gastroenterol. Hepatol. $1253,20-21$.

[68] Tang, A., Tong, Z. D., Wang, H. L., Dai, Y. X., Li, K. F., Liu, J. N., Wu, W. J., Yuan, C., Yu, M. L., Li, P., Yan, J. B. (2020) Detection of Novel Coronavirus by RT-PCRin Stool Specimen from Asymptomatic Child, China. Emerg. Infect. Dis. 26, 1337-1339.

[69] Kampf, G., Todt, D., Pfaender, S., Steinmann, E. (2020) Persistence of coronaviruses on inanimate surfaces and their inactivation with biocidal agents. J. Hosp. Infect. 104, 246-251.

[70] Chan, J. F. W., Yuan, S., Kok, K. H., To, K. K. W., Chu, H., Yang, J., Xing, F., Liu, J., Yip, C. C. Y., Poon, R. W. S., Tsoi, H. W., Lo, S. K. F., Chan, K. H., Poon, V. K. M., Chan, W. M., Ip, J. D., Cai, J. P., Cheng, V. C. C., Chen, H., Hui, C. K. M., Yuen, K. W.(2020) A familial cluster of pneu-monia associated with the 2019 novel coronavirus indicating person-to-person transmission: a study of a family cluster. Lancet $395,514-523$.

[71] Li, Q., Guan, X., Wu, P., Wang, X., Zhou, L., Tong, Y., Ren, R., Leung, K. S. M., Lau, E. H. Y., Wong, J. Y., Xing, X., Xiang, N., Wu, Y., Li, C., Chen, Q., Li, D., Liu, T., Zhao, J., Liu, M., Tu, W., Chen, C., Jin, L., Yang, R., Wang, Q., Zhou, S., Wang, R., Liu, H., Luo, Y., Liu, Y., Shao, G., Li, H., Tao, Z., Yang, Y., Deng, Z., Liu, B., Ma, Z., Zhang, Y., Shi, G., Lam, T. T. Y., Wu, J. T., Gao, G. F., Cowling, B. J., Yang, B., Leung, G. M., Feng, Z.(2020) Early transmission dynamics in Wuhan, China, of novel coronavirusinfected pneumonia, N. Engl. J. Med. NEJMoa2001316.

[72] Rothe, C., Schunk, M., Sothmann, P., Bretzel, G., Froeschl, G., Wallrauch, C., Zimmer, T., Thiel, V., Janke, C., Guggemos, W. Seilmaier, M., Drosten, C., Vollmar, P., Zwirglmaier, K., Zange, S., Wolfel, R., Hoelscher, M. (2020) Transmission of 2019-nCoV infection from an asymptomatic contact in Germany. N. Engl. J. Med. NEJMc2001468.

[73] Jean, S. S., Lee, P. I., Hsueh, P. R. (2020) Treatment options for COVID-19: The reality and challenges, J. Microbiol. Immunol. Infect., DOI: 10.1016/j.jmii.2020.03.034.

[74] Dwight, L., Sternberg, M. A., Strange, U., Laufer, S., Naujokat, C. (2020) Candidate drugs against SARS-CoV-2 and COVID-19. Pharmacol. Res. DOI: 10.1016/j.phrs.2020.104859.

[75] Caoa, Y., Denga, Q., Daib, S. (2020) Remdesivir for severe acute respiratory syndrome coronavirus 2 causing COVID-19: An evaluation of the evidence. Travel Med. Infect. Dis. DOI: 10.1016/j.tmaid.2020.101647.

[76] Wang, M., Cao, R., Zhang, L., Yang, X., Liu, J., Xu, M., Shi, Z., Hu, Z., Zhong, W., Xiao, G. (2020) Remdesivir and chloroquine effectively inhibit the recently emerged novel coronavirus (2019nCoV) in vitro, Cell Res. 30, 269-271.
[77] Grein, J. et al. (2020) Compassionate use of remdesivir for patients with severe COVID-19, N. Engl. J. Med, DOI 10.1056/NEJMoa2007016.

[78] Xinhua Net. Favipiravir shows good clinical efficacy in treating COVID-19: http://www.xinhuanet.com/english/2020 03/17/c 138888226.htm.

[79] Cao, B. et al. (2020) A trial of lopinavir-ritonavir in adults hospitalized with severe COVID-19. $N$ Engl J Med., DOI 10.1056/NEJMoa 2001282

[80] NCT04315948, ClinicalTrials.gov, (2020), March 20.

[81] Gao, J., Tian, Z., Yang, X. (2020) Breakthrough: Chloroquine phosphate has shown apparent efficacy in treatment of COVID-19 associated pneumonia in clinical studies. Biosci. Trends 14, 72-73.

[82] Stahlmann, R., Lode, H. (2020) Medication for COVID-19 - an overview of approaches currently under study. Dtsch Arztebl Int 117, 213-219.

[83] Yao, X., Ye, F., Zhang, M., Cui, C., Huang, B., Nui, P., Liu, X., Zhao, E. D., Song, C., Zhan, S., Lu, R., Li, H., Tan, W., Liu, D. (2020) In vitro antiviral activity and projection of optimized dosing design of hydroxychloroquine for the treatment of severe acute respiratory syndrome coronavirus 2 (SARS-CoV-2). Clin. Infect. Dis. DOI: $10.1093 /$ cid/ciaa237.

[84] Gautret, P., Lagier, J. C., Parola, P., Hoang, V. T., Meddeb, L., Mailhe, M., Doudier, B., Courjon, J., Giordanengo, V., Viera, V. E., Dupont, H. T., Honore, S., Colson, P., Chabriere, E., La Scola, B., Rolain, J. M., Brouqui, P., Roult, D. (2020) Hydroxychloroquine and azithromycin as a treatment of COVID-19: results of an open-label non-randomized clinical trial. Int. J. Antimicrob. Agents. DOI: 10.1016/j.ijantimicag.2020.105949.

[85] Chen, Z., Hu, J., Zhang, Z., Jiang, S., Han, S., Yan, D., Zhuang, R. Hu, B., Zhang, Z. (2020) Efficacy of hydroxychloroquine in patients with COVID-19: results of a randomized clinical trial. medRXiv. DOI: 10.1101/2020.03.22.20040758.

[86] Qamar, Md. T., Alqahtani, S. M., Alamri, M. A., Chen, L. L. (2020) Structural basis of SARS-CoV-2 3CLpro and anti-COVID-19 drug discovery from medicinal plants. J. Pharm. Anal. DOI: 10.1016/j.jpha.2020.03.009

[87] Khandelwal, A., Sharma, T. (2020) Computational Screening of Phytochemicals from Medicinal plants as COVID-19 Inhibitors. ChemRxiv. Preprint, DOI: 10.26434/chemrxiv.12320273.v1.

[88] Rojas, M., Rodriguez, Y., Diana, M., Monsalve, Acosta-Ampudia Y., Camacho, B., Gallo, J. E., Rojas-Villarraga, A., RamírezSantana, C., Juan, C., Coronado, D., Manrique, R., Mantilla, R. D., Shoenfeld, Y., Anaya, J. M. (2020) Convalescent plasma in Covid19: Possible mechanisms of action. Autoimmun. Rev. DOI 10.1016/j.autrev.2020.102554

[89] Shen, C., Wang, Z., Zhao, F., Yang, Y., Li, J., Yuan, J., Wang, F., Li, D., Yang, M., Xing, L., Wei, J., Xiao, H., Yang, Y., Qu, J., Qing, L., Chen, L., Xu, Z., Peng, L., Li, Y., Zheng, H., Chen, F., Huang, K., Jiang, Y., Liu, D., Zhang, Z., Liu, Y., Liu, L. (2020) Treatment of 5 Critically Ill Patients With COVID-19 With Convalescent Plasma. J. Am. Med. Assoc. 323, 1582-1589.

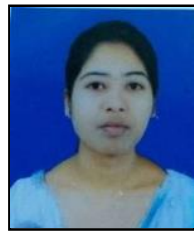

Dr. Roshni Kumari was born in a beautiful city of Jharkhand named Giridih, India. She received her B.Sc. (Chemistry) from Vinoba Bhave University, Jharkhand and M.Sc. (Chemistry) from Ranchi University, Jharkhand. Thereafter she moved to Central University of Jharkhand in 2015 and joined as PhD scholar to obtain the Doctoral degree under the supervision of Dr. Soumen Dey. She then qualified UGC-NET (L.S) in Environmental Sciences in 2018. She received a Ph.D. in the year 2020 The area of research included eco-friendly synthesis and use of natural material for removal of toxicity. Real samples were also analysed for commercial viability.

So far, she has published 8 papers in reputed journals and is continuing to develop environment friendly methods for wastewater treatment toward greener and sustainable earth. Various natural materials have been developed as potential adsorbents. Binary and ternary metal oxide nanoparticles have been recently synthesized and used as potential materials for wastewater treatment. The pandemic situation and the interest in biochemistry motivated her to summarize a review article on COVID-19. Some notable publications are as follows:

1. Kumari, R.; Khan, Md. A.; Mahto, M.; Qaiyum,Md. A. Mohanta, J.; Dey, B.; Dey. S*. (2020) Dewaxed Honeycomb as a Promising Scavenger for Malachite Green from Water, ACS Omega, 5: 19548-19556. 
2. Kumari, R., \& Dey, S*. (2019). A breakthrough column study for removal of malachite green using coco-peat. International Journal of Phytoremediation, 21(12), 1263-1271.

3. Kumari, R.; Dey, S*. (2019) Synthesis of Porous Iron - Zirconium mixed oxide Fabricated Ethylene diamine composite for removal of Cationic dye, Desalination and Water Treatment, 158, 319-329.

She has presented her work at several International and National conferences and seminars. She is passionate about teaching and promotes knowledge oriented lectures for students and also takes practical classes for students during her research study in the University. She is keenly interested in research related to environmental chemistry, synthetic chemistry and biochemistry and is dedicated to participating actively in such areas in near future.

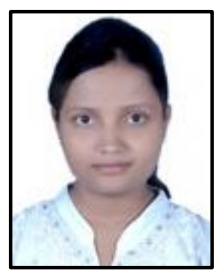

Miss Kumari Pragati Nanda was born in city Ranchi, capital of state Jharkhand, India. She received her B.Sc. (Zoology) from Ranchi University, Jharkhand and M.Sc. (Life Sciences) from Central University of Jharkhand, Jharkhand in 2015 Thereafter she joined as research scholar in Department of Life Sciences of Central University of Jharkhand to obtain the Doctoral degree under the supervision of Dr. Hena Firdaus in 2015 afte qualifying GATE in 2015. She then qualified Joint CSIR-UGC-NET (JRF), AIR 104 in Life Sciences in 2016. She is pursuing PhD (as SRF) and title of her Ph.D. thesis is Assessment of heavy metal toxicity on Drosophila melanogaster's health and immunity.

So far, she has published 3 papers and 1 book chapter in well reputed and peer reviewed journals and is trying to discover more ways to understand biological effects of different heavy metals on model organism Drosophila melanogaster, for better understanding of heavy metal toxicity. Being a life science student, this pandemic situation gave her opportunity to write some important and useful facts for wellness of society. And hence she motivated her to summarize a review article on COVID-19. Some of her publications are as follows:

1. Nanda, K. P., Kumari, C., Dubey, M. and Firdaus, H*. (2019) Chronic lead $(\mathrm{Pb})$ exposure results in diminished hemocyte count and increased susceptibility to bacterial infection in Drosophila melanogaster. Chemosphere, 236, 124349.

2. Dubey, M., Nanda, K. P. and Firdaus, H. (2018). Behavioural Assessment of Muscle Development by Downregulating Different types of Integrins in Drosophila melanogaster. Research \& Reviews: A Journal of Life Sciences, 8:2.

3. Nanda, K. P., Akhtar, N., Das, A. K. and Thakur, A. K*. (2013) Studies on the zooplankton diversity in Kanke dam Ranchi Jharkhand Biospectra, 8(1), pp91-96.

She got selected for DBT Builder Scholarship for MSc project in 2015 in Department of Life Sciences in Central University of Jharkhand. Also, she has presented her work at many National and International conferences, seminars, and summits. She got Best poster presentation award in National seminar on Environmental and Biotechnological prospects and issues in India 2017 organized by Ranchi women's college Ranchi University and Best oral presentation award in International Conference on Advances in environmental and agricultural biotechnology-2018, organized by St. Xavier's College, Ranchi. She likes teaching and takes theoretical and laboratory lectures for students. She is strongly interested in research and development field related to genetics, molecular biology, environmental science and biochemistry for which she is actively tryingto learn and apply new tools and techniques from time to time in research field.

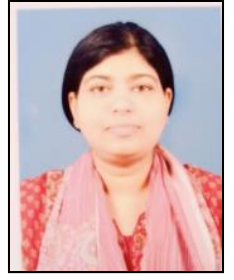

Dr. Hena Firdaus is an Assistant Professor at the Department of Life Sciences, Central University of Jharkhand (CUJ) in Ranchi, India. She completed her $\mathrm{PhD}$ at the Indian Institute of Science (IISc) Bangalore, India in the year 2010 and joined CUJ in 2011. She received her B. Sc (Hons) and MSc degree in Biochemistry from Aligarh Muslim University (AMU) where she bagged gold medal for her outstanding performance in under-graduation. She is life member of coveted societies like Society for Biological Chemist (SBC) and Indian Society of Cell Biology (ISCB). She was Co-PI in the five year project (2014-2019) funded by DBT-Boost to University Interdisciplinary Life science Departments for Education and Research (BUILDER). Currently her lab at CUJ is using Drosophila as model organism to assess toxicity of various environmental pollutants as well as deciphering roles of genes involved in muscle development by utilizing vast resources of genetic toolbox. The lab findings have been published in prominent journal as well as book chapter. Some representative publications are as follows:

- Nanda KP, Kumari C, Dubey M, Firdaus H* (2019) Chronic lead (Pb) exposure results in diminished hemocyte count and increased susceptibility to bacterial infection in Drosophila melanogaster. Chemosphere, 236 , 124349. DOI: 10.1016/j.chemosphere.2019.124349.

- Dubey M, Nanda KP, Firdaus H* (2020) Cryodis section and tissue preparation of Drosophila thorax for indirect flight muscle imaging. In: fundamental approaches to screen abnormalities in Drosophila. Monalisa M (Ed.), Springer, NY 65-76. DOI: 10.1007/978-1-4939-9756-5_6.

- Dubey M, Ain U, Firdaus $\mathrm{H}^{*}$ (2020) An insight on Drosophila myogenesis and its assessment techniques. Mol Biol Rep, DOI: 10.1007/s11033-020-06006-0 (Accepted manuscript).

Apart from academics Dr. Firdaus also takes active participation in various Institutional Management Committees; like the Board of Studies (BoS), Research Advisory Council (RAC), Institutional animal ethical committee (IAEC), Institutional Biosafety committee (IBSC) and Institutional Human Ethical committee (IHEC). She is also representing her University as National Service Scheme (NSS) program officer where along with her NSS student volunteers she is involved in various community services. NSS was established by Government of India (GoI) with the idea of involving students in the task of national service which dates back to the times of father of the nation, Mahatma Gandhi.

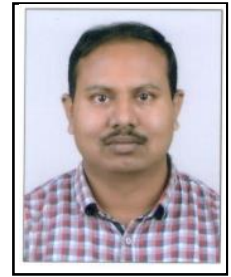

Dr. Soumen Dey was born in Kolkata, India on $16^{\text {th }}$ February 1977. He received his B.Sc., M.Sc. (Chemistry), and B.Ed. degrees from Visva Bharati University, Santiniketan (established by the great Rabindranath Tagore, the first Asian Nobel laureate). Thereafter he moved to Presidency University in 2001 and joined as JRF in a project on Arsenic poisoning. He then qualified CSIR-UGC-NET JR Fin 2002 and joined the group of Prof. Sabyasachi Sarkar at I.I.T. Kanpur, India. He received a Ph.D. in the year 2009.The area of research was the eco-friendly synthesis and hostguest sensing by calixpyrrole based macromolecules. Reactivity with higher valent transition metals has been well demonstrated. $\mathrm{He}$ is experienced in spectroscopic, and crystallographic techniques.

He joined as an ASSISTANT PROFESSOR in the Department of Chemistry, S.K.M. University Dumka, India in 2008. In 2011, he moved to the Central University of Jharkhand where he is working as a senior ASSISTANT PROFESSOR. So far, he has published 21 research papers in reputed journals and 3 book chapters. He has successfully guided 3 students for their Ph.D. and 31 students for their Master's dissertations. He received major research grant under DST Young Scientist Scheme in 2013. Hi current research area is to develop environmentally benign techniques for wastewater treatment towards safer health. Various plant-derived materials have been demonstrated as phytosorbents. Magnetic metal oxide nanoparticles have been recently synthesized and used as potential and sustainable materials for water treatment. Some representative publications are as follows:

1. Mohanta, J.; Dey, B.; Dey S*. (2020) Magnetic Cobalt Oxide Nanoparticles: Sucrose-Assisted Self-Sustained Combustion Synthesis, Characterization, and Efficient Removal of Malachite Green from Water. J. Chem. Eng. Data, 65: 2819-2829.

2. Kumari,R.; Khan, Md. A.; Mahto, M.; Qaiyum, Md. A. Mohanta, J.; Dey, B.; Dey. S*. (2020) Dewaxed Honeycomb as a Promising Scavenger for Malachite Green from Water, ACS Omega, 5: 19548-19556.

3. Kumari, R., \& Dey, S*. (2019). A breakthrough column study for removal of malachite green using coco-peat. International Journal of Phytoremediation, 21(12), 1263-1271.

Dr. Dey is the twice recipient of 'YOUNG SCIENTIST AWARD' conferred by the Indian Chemical Society in the year 2002 and 2008. He has delivered about 10 invited lectures at various scientific meetings. He is currently a reviewer of many prestigious journals such as Journal of Chemical \& Engineering Data (ACS), Environmental Progress (Wiley), Journal of Chemical\& Environmental Engineering (Elsevier), and International Journal of Phytoremediation (Taylor and Francis). Dr. Dey is a member of various coveted societies such as the American Chemical Society, Chemical Research Society of India, Indian Council of Chemists, and I.I.T. Kanpur Alumni Association. Apart from academics he also actively takes part in Institutional Management committees; the Academic Council (2015-2020), Board of Studies, Research Advisory Council, and Board of Research. He held the position of 'Coordinator' of the Department of Education (2014-17). Besides, he actively contributed as hostel Warden for the good living of the students. As a part of outreach activity and socia responsibility, Dr. Dey has trained many school teachers to teach Chemical Sciences. 